\title{
Factors Influencing Consumers' Decision to Purchase Food in Environmentally Friendly Packaging: What Do We Know and Where Do We Go from Here?
}

\author{
Igor Popovic $^{1, *}$, Bart A. G. Bossink ${ }^{2}$ and Peter C. van der Sijde ${ }^{3}$ \\ 1 School of Business and Economics, Vrije Universiteit Amsterdam, De Boelelaan 1105, 1081 HV Amsterdam, \\ The Netherlands \\ 2 Faculty of Sciences, Vrije Universiteit Amsterdam, De Boelelaan 1105, 1081 HV Amsterdam, \\ The Netherlands; b.a.g.bossink@vu.nl \\ 3 Faculty of Social Sciences, Vrije Universiteit Amsterdam, De Boelelaan 1105, 1081 HV Amsterdam, \\ The Netherlands; p.c.vander.sijde@vu.nl \\ * Correspondence: i.popovic@vu.nl
}

Received: 1 November 2019; Accepted: 9 December 2019; Published: 16 December 2019

\begin{abstract}
While many food producers invest in adopting sustainable and/or environmentally friendly packaging for regular foods, such as milk or juice, it remains unclear why consumers choose to buy regular food in such packaging, especially when it is more expensive and other alternatives are available. The purpose of this paper is to present a systematic literature review of all studies on the predictors of consumer food purchasing in environmentally friendly packaging published in the period 1994-2019. The guiding research question of this study is: Which factors influence the consumers' decision to purchase food in environmentally friendly packaging? To review the extant research on the factors influencing consumers' decision to purchase food in environmentally friendly packaging, we employed a systematic literature review methodology. The review revealed that, although the extant research is growing, it is very limited in terms of the theories utilized to explain consumer purchasing behavior and in the range of the tested predictors of consumers' purchasing of foods in environmentally friendly packaging. Among the existing explanations are demographics, consumer attitudes, knowledge about the environmental effects of packaging, visual designs, functionality, cross-cultural differences, and affordability. The paper is concluded with a discussion of the implications of this systematic literature review for future research and practice. Among the leading recommendations are: (a) to go beyond Ajzen's theoretical explanations of consumer purchasing behaviors; (b) to examine a broader set of predictors; (c) to draw on more interconnected complex models that include both internal and external factors; (d) to conduct cross-cultural comparative studies; (e) to address the gap between attitudes and behaviors; and (f) to consider the role of organizations and government in the transition to more sustainable consumer purchasing behavior, rather than only searching for individual predictors of behaviors.
\end{abstract}

Keywords: packaging; food; environmentally friendly; consumers behavior; sustainability; literature review

\section{Introduction}

With a growing number of food producers adopting environmentally friendly packaging for regular food, such as milk or juice, a question remains regarding why consumers choose to buy regular foods in such packaging, preferring it to more affordable, traditional packaging alternatives. In the past two and half decades, much research has emerged to address this topic. Studies show that, among the 
important factors predicting consumer purchases of food in environmentally friendly packaging are, for example, their positive attitude [1], concern for the environment [2], and functionality [3].

Despite a growing number of studies, an integrative perspective on the topic is still missing. This is especially problematic because the research evidence shows that for almost two decades, researchers have been utilizing one theory—i.e., Ajzen's Theory of Planned Behavior [4]—to explain consumer purchasing behaviors. Today, many more theories exist that offer more comprehensive and holistic explanations [5-7]. However, not many of these theories are used to explain consumer preferences for foods in environmentally friendly packaging. Moreover, a clear overview of what has been done in this area of research is missing at present.

With this study, we aim to contribute to the filling of this research gap. We conduct a systematic literature review covering the period 1994-2019, to answer the following question: Which factors influence consumers' decisions to purchase food in environmentally friendly packaging? Answering this question is important if researchers want to contribute to the knowledge of consumers' pro-environmental behaviors. It is also important if we, as scholars, want to enable food producers to serve their consumers better and with more sustainable implications for our planet.

\section{Theoretical Background}

To assess the limitations of the extant research on the predictors of consumer purchases of food in environmentally friendly packaging, we first need to establish which factors and explanations such research needs to entail. Consequently, we begin this review with an overview of the theories that explain consumers' pro-environmental purchasing behavior. Considering that the research on environmentally friendly packaging is at its nascent stage, we review general theories explaining consumer motivations for pro-environmental behavior.

The research shows that the extant models of individual pro-environmental behavior can be organized in at least five theoretical perspectives, as follows: An attitudinal perspective, a responsible perspective, an altruistic perspective, a sociological perspective, and finally, a pro-environmental consciousness perspective. Below is a brief description of each perspective.

\subsection{An Attitudinal Perspective}

The first models explaining consumers' pro-environmental behaviors were developed in the 1970s. They were based on the simple assumption that if you raise the individual's environmental knowledge, it would raise the individual's awareness, which would consequently lead to environmentally friendly behavior [8]. However, the reality proved to be very different and increased knowledge was not found to lead to any significant increase in pro-environmental behaviors [5]. The research findings suggested a need for more complex models and theories to explain people's pro-environmental behaviors [9]. Specifically, they called for the following aspects to be considered:

(a) Knowing does not mean doing: The research showed that direct experiences have a stronger influence on people's behaviors than indirect experiences, such as knowledge [10];

(b) Social norms drive behavior: Social norms, including family, cultural traditions, and customs, shape people's attitudes and consequent behaviors [11];

(c) Attitudes change over time: Various factors, such as new information, emergent knowledge, and emergent scientific findings, predict the shifting nature of attitudes [12];

(d) Specific attitudes, rather than general attitudes, matter: The research found that while general attitudes might be positive, when focusing on specific attitudes, the latter might not be in accordance with general attitudes [13].

To accommodate the following conditions, both scholars and practitioners turned to Ajzen and Fishbein's Theory of Planned Behavior [4]. The theory suggests that people are essentially rational, in that they "make systematic use of information available to them" and are not "controlled by unconscious motives or overpowering desires", nor is their behavior "capricious or thoughtless" [4] (p. 5). Attitudes 
do not determine behavior directly, rather they influence behavioral intentions, which in turn, shape our actions. Intentions are not only influenced by attitudes, but also by social ('normative') pressures. Thus, "the ultimate determinants of any behavior are the behavioral beliefs concerning its consequences and normative beliefs concerning the prescriptions of others" [4] (p. 239). This model prevailed in the pro-environmental behavior research for many years, and many contemporary models still continue to use Ajzen and Fishbein's Theory of Planned Behavior as a basis [14].

\subsection{A Responsible Perspective}

In 1986, Hines, Hungerford, and Tomera proposed a Model of Responsible Environmental Behavior [15]. While basing their theoretical assumptions on Ajzen and Fishbein's theory of planned behavior [15-17], they also included in their new model their findings from a meta-analysis of 128 pro-environmental behavior research studies. The new model included the following variables that were found to associate with responsible pro-environmental behavior:

(a) Knowledge of issues: The consumer needs to be familiar with the environmental problem and its causes;

(b) Knowledge of action strategies: The consumer needs to know how he/she needs to act to lower his or her impact on the environmental problem;

(c) Locus of control: The consumer needs to believe in his/her ability to bring about change through his or her own behavior;

(d) Attitudes: The consumer needs to have a strong pro-environmental attitude to engage in pro-environmental behavior;

(e) Verbal commitment: The consumer needs to willingly communicate his/her intentions to behave pro-environmentally;

(f) Individual sense of responsibility: The consumer needs to possess a high sense of personal responsibility.

While the model developed by Hines et al. [15] was a significant improvement to the previous models explaining consumers' pro-environmental choices, it was still found to be insufficiently comprehensive. Many more factors were suggested to influence pro-environmental behavior, among which are 'situational factors', which include economic constraints, social pressures, and opportunities to choose different actions [15].

\subsection{An Altruistic Perspective}

In the 1990s, scholars focused on altruistic explanations for human pro-environmental behaviors. The following two assumptions were central in the emerging theories [5]:

(a) People with a strong self-orientation are less likely to act ecologically;

(b) People who have satisfied their personal needs are more likely to act ecologically because they have the resources (time, money, energy) to care about social and pro-environmental goals.

However, the study of Stern et al. [18] showed that individuals with an egoistic orientation were more likely to engage in pro-environmental behavior as long as the action serves the person's needs and wants (e.g., taking the train instead of the car to have time to relax and read). At the same time, with regards to assumption two, scholars found that people from poorer nations do not necessarily act less ecologically [19].

\subsection{A Sociological Perspective}

Blake [20] proposed that the models explaining peoples' pro-environmental choices and behaviors need to move beyond psychological explanations and focus on social and institutional enablers and barriers. Specifically, he highlighted the influence of three barriers to action, i.e., individuality, 
responsibility, and practicality. Individual barriers are the barriers lying within the person and relate to attitudes and temperament. These barriers are especially relevant when people do not have a strong environmental orientation. Responsibility concerns 'locus of control'. People who do not act pro-environmentally feel that they cannot influence the situation. Blake [20] notes that a lack of trust in the local and national government often stops people from acting pro-environmentally. Finally, practicality refers to the social and institutional constraints that prevent people from acting pro-environmentally regardless of their attitudes or intentions. Blake [20] lists such constraints as lack of time, lack of money, and lack of information.

While this model was found to be a great improvement to the limited models previously developed, it still omitted some important factors, such as family and cultural norms [5].

\subsection{A Pro-Environmental Consciousness Perspective}

Recently, Kollmuss and Agyeman [5] noted that most theoretical models omit the influence of the desire for comfort and convenience, personality traits, and character. Therefore, they proposed a "pro-environmental consciousness" model. While including all other factors, such as external factors (i.e., infrastructure, political, economic, social, and cultural factors) and various barriers (lack of environmental consciousness, lack of incentives, insufficient feedback about behavior, etc.), they also proposed including internal factors, such as environmental consciousness, functionality and ease of use.

In summary, the above-described models suggest that at least three sets of factors explain the individual's motivations to act pro-environmentally: (a) Demographic factors, (b) external factors (e.g., institutional, economic, social, and cultural factors), and (c) internal factors (e.g., motivation, environmental knowledge, awareness, values, attitudes, emotion, locus of control, responsibilities, and purchasing priorities, for example, functionality) [5]. We now review how these factors have been accommodated by the research on environmentally friendly packaging.

\section{Methodology}

To explore how the contemporary research on environmentally friendly packaging accommodated key theoretical developments in this area of research and to answer the question of which factors influence the consumers' decision to purchase food in environmentally friendly packaging, we conducted a literature review. We followed the literature review methodology described by Transfield et al. [21]. This approach seeks to remove the subjectivity of data collection by using predefined selection criteria. The review process consisted of the following three steps: Data collection, data analysis, and reporting of the results. Each step is described below.

\subsection{Data Collection}

To begin our search, we first decided on the search terms. Considering the different terms used to describe environmentally friendly packaging, we used several terms to search for published work. Specifically, we searched for "environmentally friendly packaging", "sustainable packaging", "biopackaging", and "green packaging". Given the novelty of the research area, we searched for studies through both (a) a rigorous database of established journal publications titled the ISI Web of Knowledge's Social Sciences Citation Index (SSCI) database, and (b) Google Scholar. The use of Google Scholar was important to assure that all relevant studies are included. The ISI Web of Knowledge mainly includes highly ranked journals. However, many of the studies published on the topic of environmentally friendly packaging are not included in this category.

\subsection{Data Analysis}

We limited our search to a period of 25 years (1994-2019). The starting date of the review is associated with the publication of the first study by Van Dam and Van Trijp (1994) in this area [22]. The initial search process yielded 246 studies. For this selection of studies, we manually checked 
their content to assess their suitability and identified a number of studies that did not fit our content interests. Among the excluded studies were those that focused on food rather than on the packaging, or were concerned with the packaging and its material. As a result of the manual check, 215 studies were excluded from the analysis. As a result, our final sample included 31 studies. An overview of the studies is presented in Table 1.

Table 1. An overview of the reviewed studies and their findings.

\begin{tabular}{|c|c|c|c|c|}
\hline References & Research Focus & Sample & Theory Used & Key Findings \\
\hline $\begin{array}{l}\text { Van Dam and van } \\
\text { Trijp (1994) [22] }\end{array}$ & $\begin{array}{l}\text { Examines } \\
\text { consumers' } \\
\text { understanding, } \\
\text { preference and } \\
\text { effects on decision } \\
\text { making with } \\
\text { regards to } \\
\text { purchasing } \\
\text { beverages in } \\
\text { environmentally } \\
\text { friendly packaging. }\end{array}$ & $\begin{array}{l}77 \text { Dutch } \\
\text { consumers }\end{array}$ & $\begin{array}{l}\text { A consumer } \\
\text { dilemma between } \\
\text { societal needs and } \\
\text { personal benefits } \\
\text { (Meffert, 1993) [34] }\end{array}$ & $\begin{array}{l}\text { Product packaging is a salient } \\
\text { aspect in consumers' product } \\
\text { perception. However, when } \\
\text { buying products, consumers } \\
\text { also consider convenience. The } \\
\text { importance they ascribe to } \\
\text { environmental aspects is } \\
\text { product specific, and not } \\
\text { general. }\end{array}$ \\
\hline $\begin{array}{l}\text { Van Dam (1996) } \\
\text { [35] }\end{array}$ & $\begin{array}{l}\text { Examines the } \\
\text { perceived } \\
\text { environmental } \\
\text { friendliness of } \\
\text { various types of } \\
\text { packaging for } \\
\text { different types of } \\
\text { products. }\end{array}$ & $\begin{array}{l}\text { Study 1: } 67 \text { Dutch } \\
\text { consumers Study 2: } \\
77 \text { Dutch } \\
\text { consumers Study 3: } \\
\text { 14 Dutch } \\
\text { consumers }\end{array}$ & $\begin{array}{l}\text { Consumer beliefs } \\
\text { concerning the } \\
\text { environmental } \\
\text { friendliness of } \\
\text { packaging } \\
\text { materials, } \\
\text { including } \\
\text { simplified } \\
\text { heuristics (Hoyer } \\
\text { 1984) [36] and } \\
\text { widespread beliefs } \\
\text { (Bethlehem 1990). } \\
\text { [37] }\end{array}$ & $\begin{array}{l}\text { Consumers judge } \\
\text { environmental friendliness } \\
\text { mainly from the material and } \\
\text { returnability. Their perception } \\
\text { of the environmental } \\
\text { friendliness of the packaging } \\
\text { material is based on post } \\
\text { consumption waste, whereas } \\
\text { the environmental effects of } \\
\text { production are ignored. }\end{array}$ \\
\hline $\begin{array}{l}\text { Bech-Larsen (1996) } \\
\text { [24] }\end{array}$ & $\begin{array}{l}\text { Analyzes } \\
\text { consumers' } \\
\text { attitudes to the } \\
\text { functional and } \\
\text { environmental } \\
\text { consequences of } \\
\text { food packaging }\end{array}$ & $\begin{array}{l}351 \text { Danish } \\
\text { consumers }\end{array}$ & $\begin{array}{l}\text { Means-End Theory } \\
\text { (Gutman, 1982) } \\
\text { [38]; Theory of } \\
\text { Planned Behavior } \\
\text { (Ajzen, 1988) [39]; } \\
\text { Theory of Buying } \\
\text { Behavior (Howard } \\
\text { and Sheth, 1988) } \\
\text { [40] }\end{array}$ & $\begin{array}{l}\text { Sustainable packaging is } \\
\text { preferred by consumers who } \\
\text { take personal interest in the } \\
\text { packaging's environmental } \\
\text { consequences. However, this } \\
\text { preference-unlike the } \\
\text { preference for functional } \\
\text { packaging—seldom influences } \\
\text { the consumers' actual } \\
\text { purchasing decisions. The } \\
\text { purchase of food products is } \\
\text { most often characterized by } \\
\text { habit. }\end{array}$ \\
\hline $\begin{array}{l}\text { Th } \varphi \text { gersen (1999) } \\
\text { [25] }\end{array}$ & $\begin{array}{l}\text { Investigates } \\
\text { whether the claim } \\
\text { that environmental } \\
\text { attitudes are based } \\
\text { on moral reasoning } \\
\text { is valid with regard } \\
\text { to consumer } \\
\text { buying attitudes. }\end{array}$ & $\begin{array}{l}1002 \text { Danish } \\
\text { consumers }\end{array}$ & $\begin{array}{l}\text { Schwartz (1970, } \\
\text { 1977) theory of } \\
\text { moral decision } \\
\text { making [31] }\end{array}$ & $\begin{array}{l}\text { A majority of Danish } \\
\text { consumers have developed } \\
\text { personal norms about choosing } \\
\text { environment-friendly } \\
\text { packaging and the personal } \\
\text { norm is a significant predictor } \\
\text { of their (self-reported) } \\
\text { propensity to choose } \\
\text { environment-friendly } \\
\text { packaging in the supermarket } \\
\text { (whereas perceived costs have a } \\
\text { minor influence on the choice). }\end{array}$ \\
\hline
\end{tabular}


Table 1. Cont.

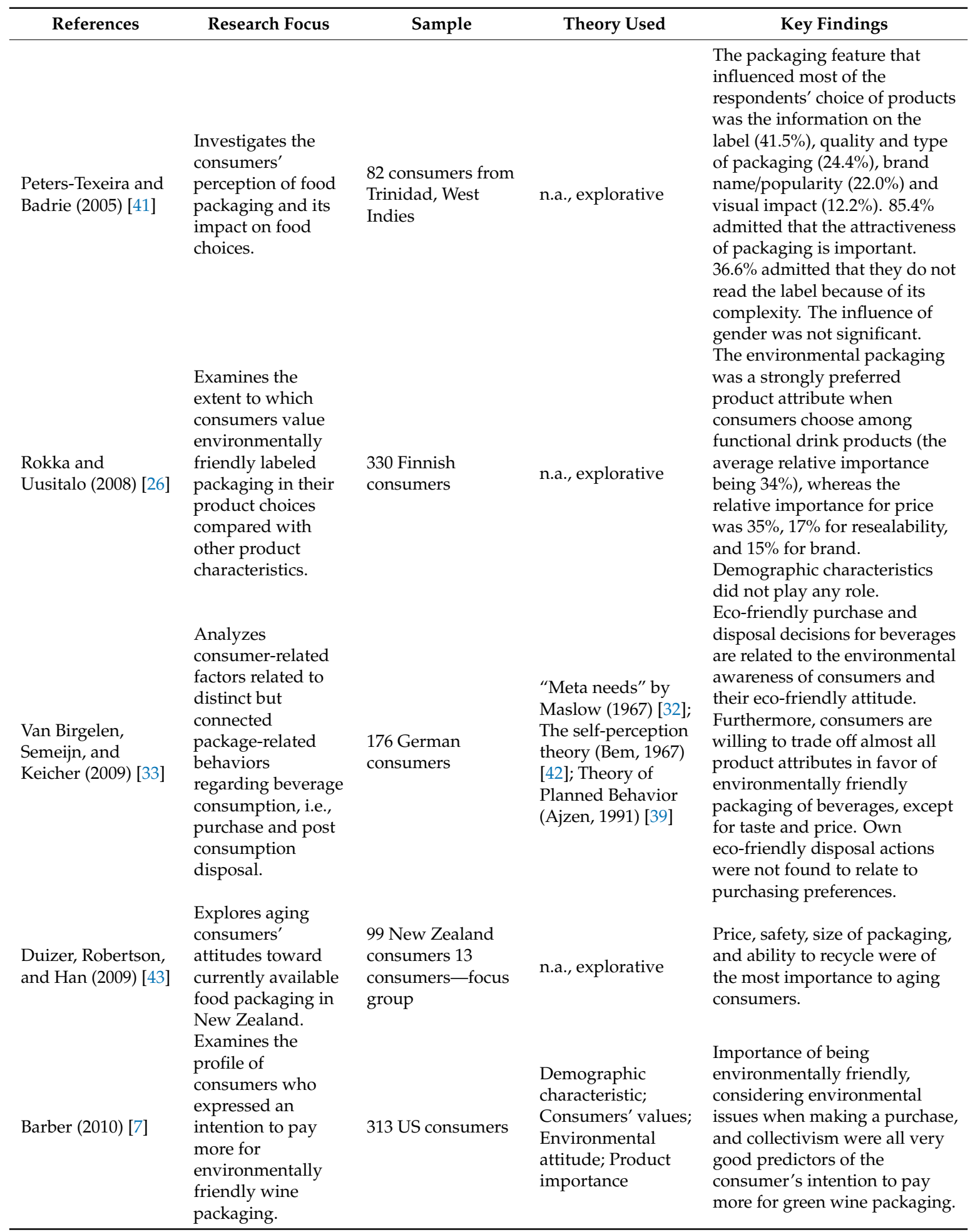


Table 1. Cont.

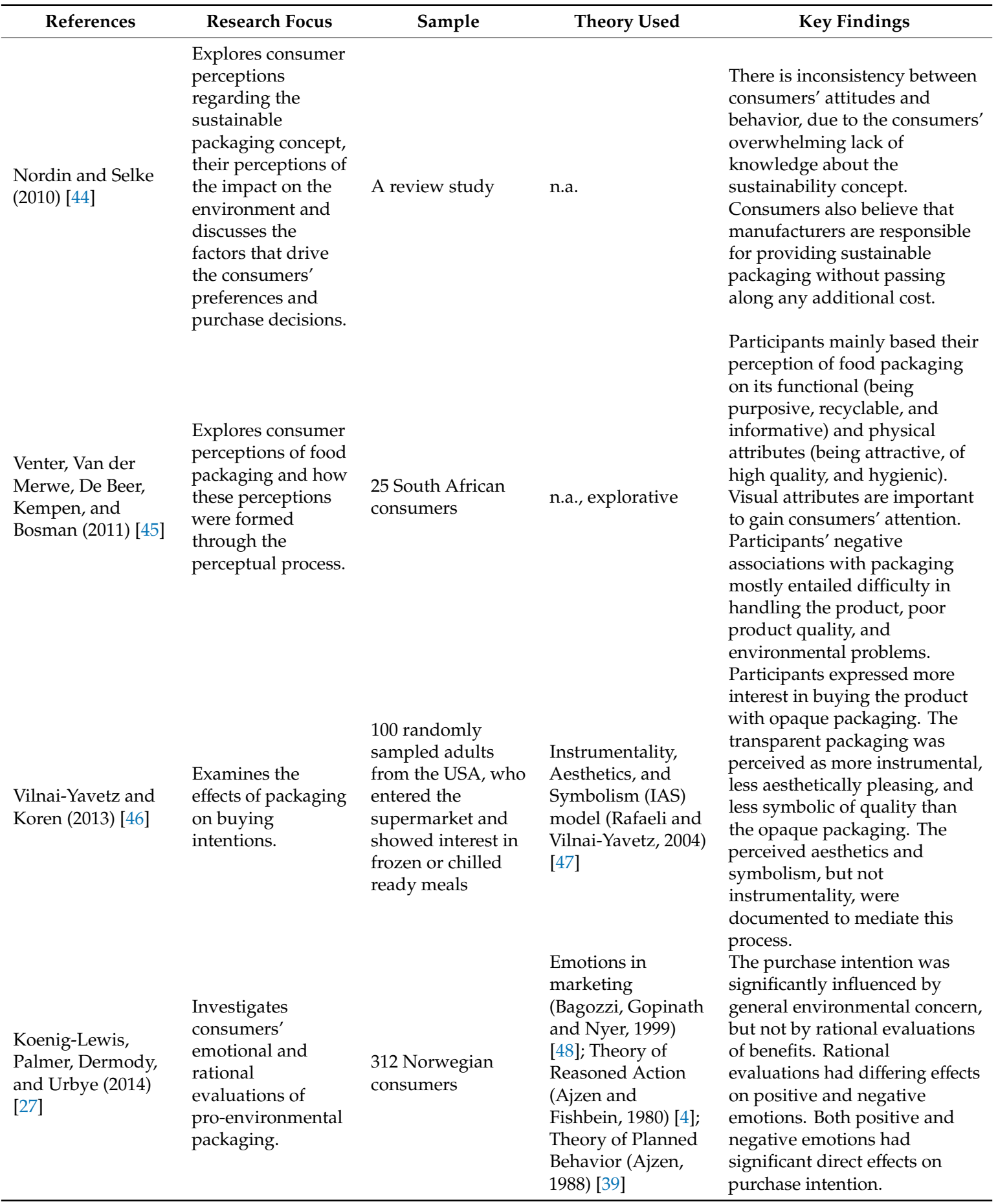


Table 1. Cont.

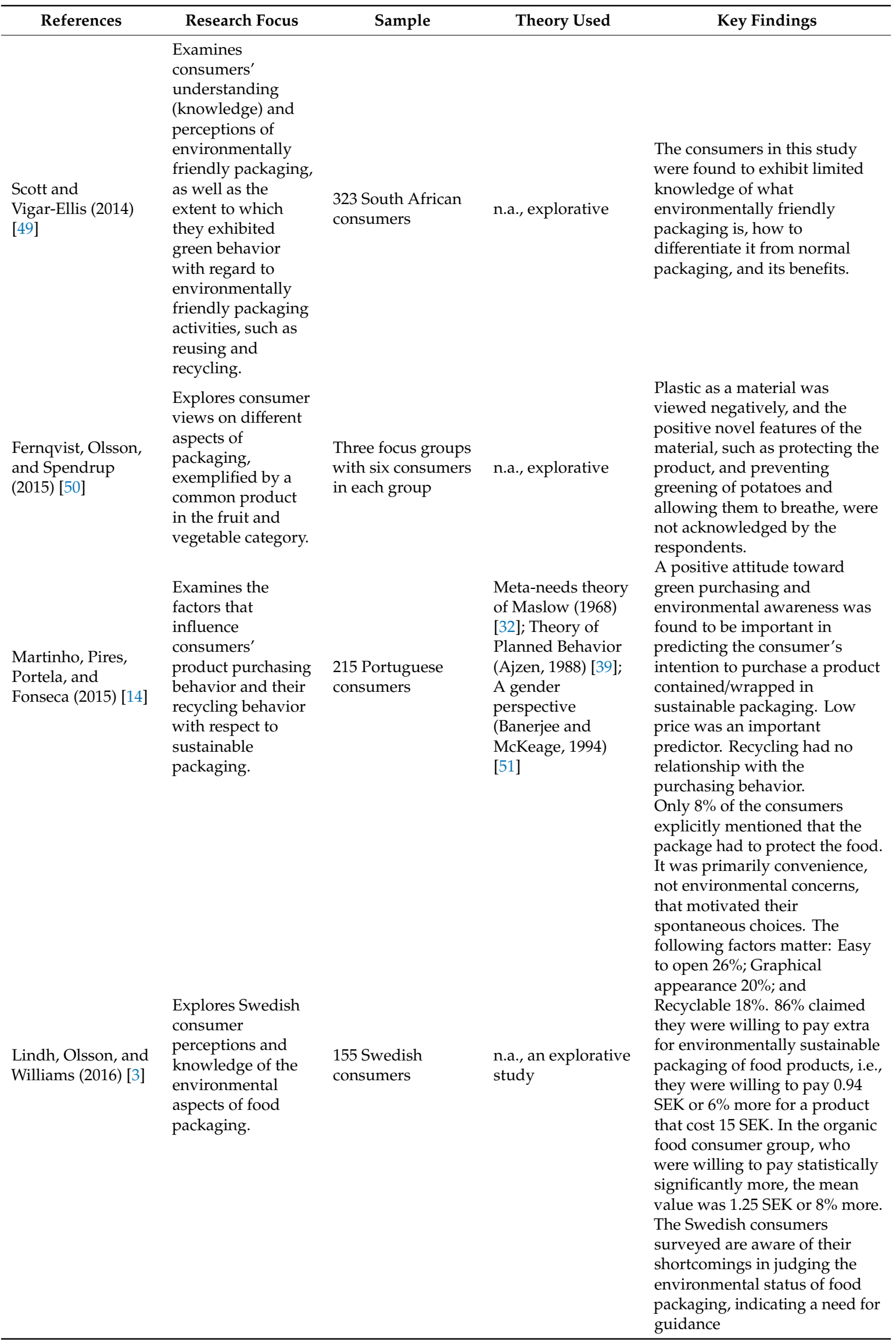


Table 1. Cont.

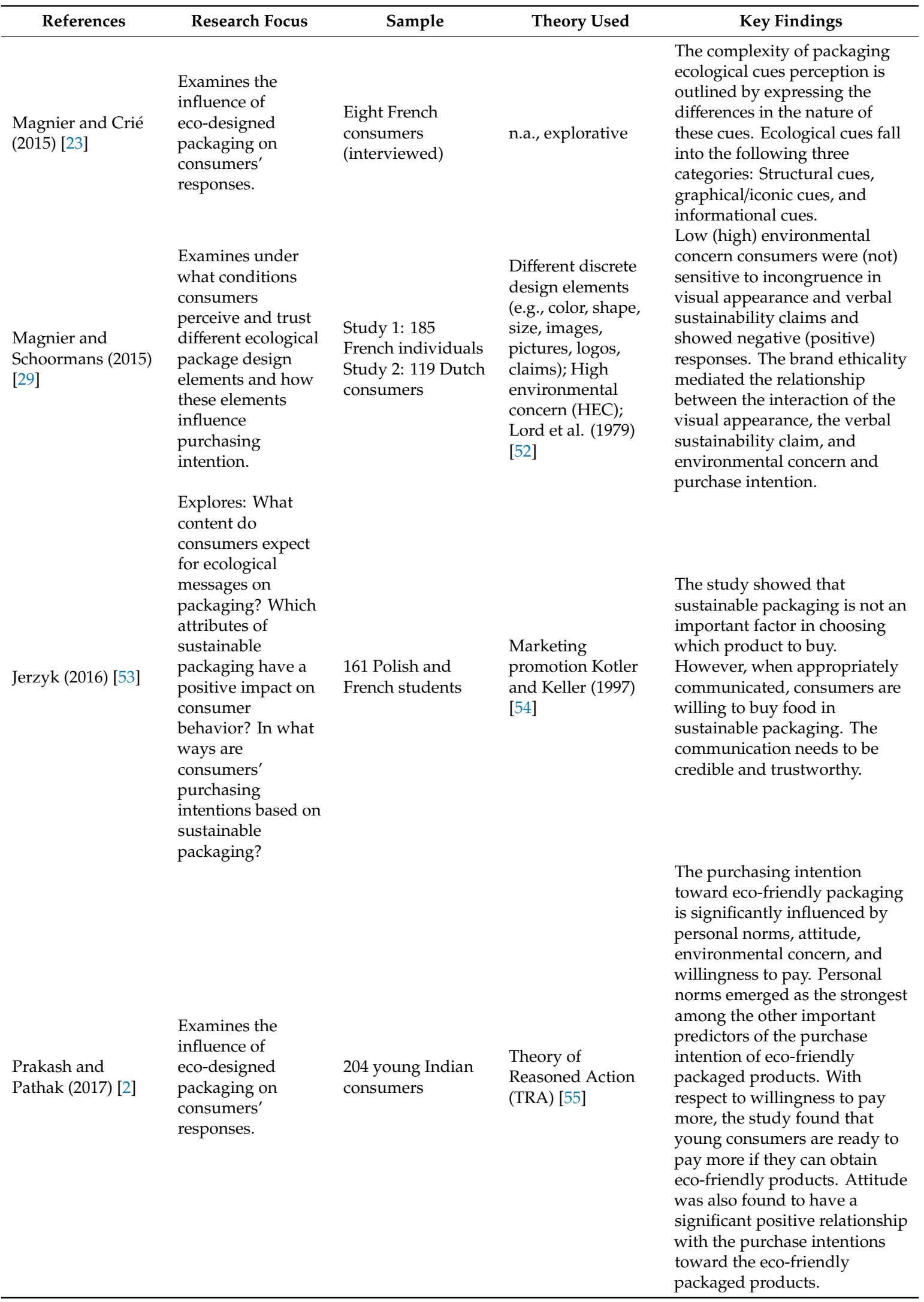


Table 1. Cont.

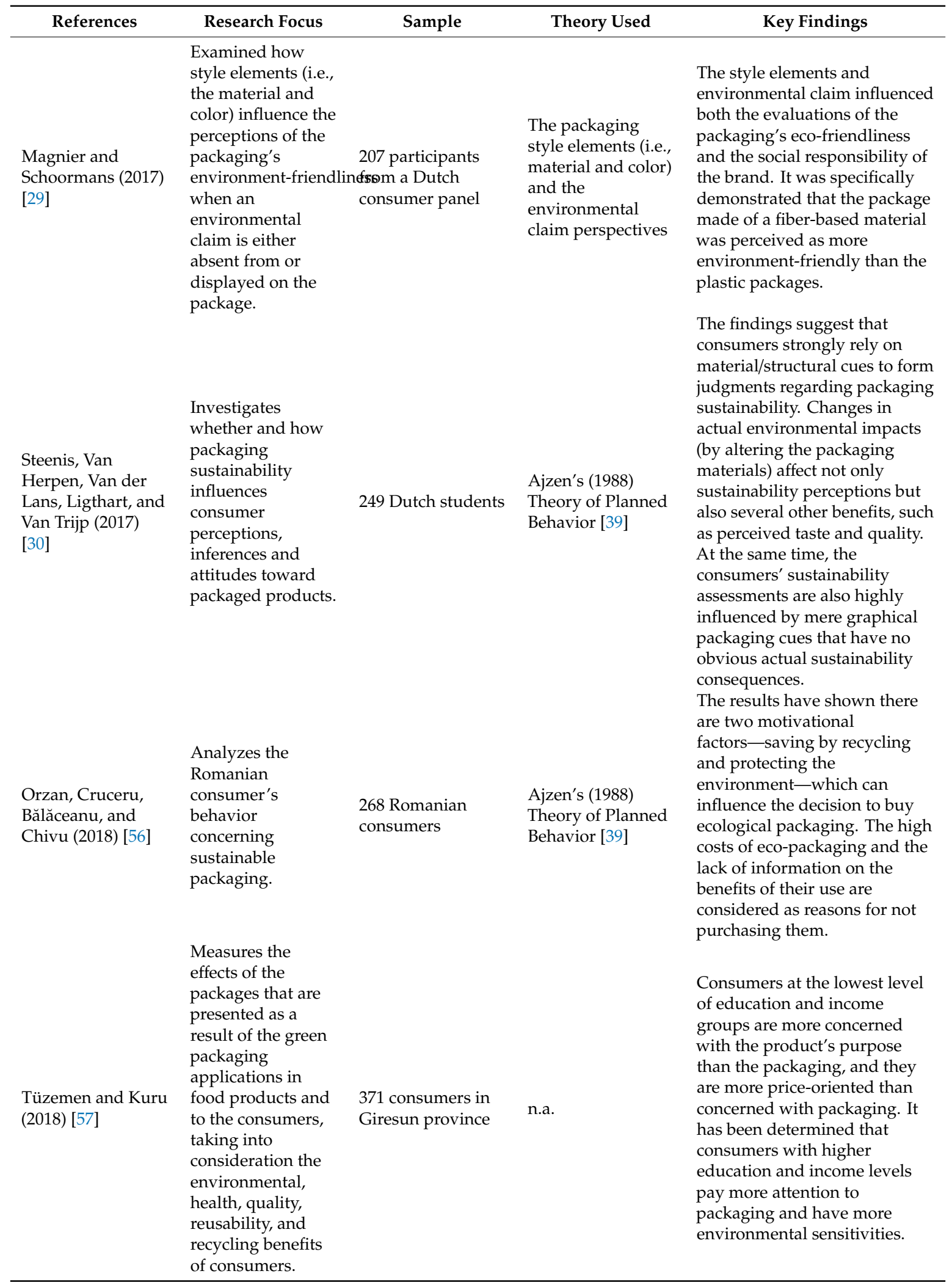


Table 1. Cont.

\begin{tabular}{|c|c|c|c|c|}
\hline References & Research Focus & Sample & Theory Used & Key Findings \\
\hline $\begin{array}{l}\text { Herbes, Beuthner } \\
\text { and Ramme (2018) } \\
\text { [61] }\end{array}$ & $\begin{array}{l}\text { Examines how the } \\
\text { interplay of } \\
\text { environmentally } \\
\text { friendly packaging } \\
\text { attributes influence } \\
\text { an overall } \\
\text { evaluation of } \\
\text { environmental } \\
\text { friendliness among } \\
\text { consumers from } \\
\text { different cultures. }\end{array}$ & $\begin{array}{l}948 \text { consumers } \\
\text { from Germany, } 610 \\
\text { from the U.S. and } \\
443 \text { from France }\end{array}$ & n.a. & $\begin{array}{l}\text { The study showed that } \\
\text { consumers focus } \\
\text { predominantly on the } \\
\text { end-of-life attributes of } \\
\text { packaging, although the } \\
\text { cultures differ in how they } \\
\text { weigh the relative value of } \\
\text { recyclability, reusability, and } \\
\text { biodegradability. They also } \\
\text { concern themselves less with } \\
\text { renewable origins, and almost } \\
\text { not at all with activities relating } \\
\text { to production, transport, and } \\
\text { retail use. Differences in } \\
\text { answers across cultures were } \\
\text { observed. }\end{array}$ \\
\hline $\begin{array}{l}\text { Trivedi, Patel, and } \\
\text { Acharya (2018) [62] }\end{array}$ & $\begin{array}{l}\text { Offers a } \\
\text { parsimonious } \\
\text { framework that } \\
\text { measures the major } \\
\text { antecedents of } \\
\text { environmental } \\
\text { attitude divided } \\
\text { into inward and } \\
\text { outward } \\
\text { orientation. }\end{array}$ & $\begin{array}{l}308 \text { usable } \\
\text { questionnaires } \\
\text { were obtained from } \\
\text { Indian consumers }\end{array}$ & $\begin{array}{l}\text { 'Inward } \\
\text { environmental } \\
\text { attitude' and } \\
\text { 'Outward } \\
\text { environmental } \\
\text { attitude' by } \\
\text { Leonidou et al. } \\
\text { (2010) [63] }\end{array}$ & $\begin{array}{l}\text { The results show that inward } \\
\text { environmental attitude and } \\
\text { attitude toward green } \\
\text { packaging play a pivotal role in } \\
\text { shaping the green purchase } \\
\text { intention. Surprisingly, } \\
\text { outward environmental } \\
\text { attitude was found to be } \\
\text { nonsignificant. }\end{array}$ \\
\hline $\begin{array}{l}\text { Hao, Liu, Chen, } \\
\text { Sha, Ji, and Fan } \\
(2019) \text { [28] }\end{array}$ & $\begin{array}{l}\text { Examining } \\
\text { consumers' } \\
\text { cognition and } \\
\text { willingness to pay } \\
\text { for green } \\
\text { packaging. }\end{array}$ & $\begin{array}{l}781 \text { consumers } \\
\text { from China }\end{array}$ & $\begin{array}{l}\text { Evidence-based } \\
\text { hypotheses }\end{array}$ & $\begin{array}{l}\text { Four principal factors affecting } \\
\text { consumers' willingness to pay } \\
\text { are uncovered, i.e., } \\
\text { environment, green packaging } \\
\text { quality, commodity, and } \\
\text { packaging price. According to } \\
\text { the estimation results, even } \\
\text { though the majority of } \\
\text { consumers have insufficient } \\
\text { knowledge regarding green } \\
\text { packaging, they have a fairly } \\
\text { strong willingness to pay for it. } \\
\text { Additionally, we observed that, } \\
\text { compared with the price and } \\
\text { appearance of green packaging, } \\
\text { consumers prefer to attach } \\
\text { greater importance to the } \\
\text { practicality of green packaging, } \\
\text { such as convenience, reusability, } \\
\text { and protective capability. }\end{array}$ \\
\hline
\end{tabular}


Table 1. Cont.

\begin{tabular}{|c|c|c|c|c|}
\hline References & Research Focus & Sample & Theory Used & Key Findings \\
\hline $\begin{array}{l}\text { Boesen, Bey, and } \\
\text { Niero (2019) [64] }\end{array}$ & $\begin{array}{l}\text { Investigates } \\
\text { whether } \\
\text { well-educated } \\
\text { young consumers } \\
\text { living in Denmark } \\
\text { understand the } \\
\text { environmental } \\
\text { sustainability of } \\
\text { five different types } \\
\text { of packaging for } \\
\text { liquid food (milk, } \\
\text { beer, soft drink, } \\
\text { olive oil, and } \\
\text { skinned tomatoes). }\end{array}$ & $\begin{array}{l}197 \text { Danish } \\
\text { consumers }\end{array}$ & $\begin{array}{l}\text { Consumer research; } \\
\text { Life Cycle } \\
\text { Assessment }\end{array}$ & $\begin{array}{l}\text { Consumers assess the } \\
\text { environmental sustainability of } \\
\text { the tested types of packaging, } \\
\text { primarily based on the material } \\
\text { type and on what they can } \\
\text { personally do at the disposal } \\
\text { stage. Consumers have limited } \\
\text { knowledge of } \\
\text { sustainability-related } \\
\text { eco-labels. }\end{array}$ \\
\hline $\begin{array}{l}\text { Dilkes-Hoffman, } \\
\text { Pratt, Laycock, } \\
\text { Ashworth, and } \\
\text { Lant (2019) [1] }\end{array}$ & $\begin{array}{l}\text { Examines public } \\
\text { beliefs and } \\
\text { attitudes toward } \\
\text { plastics in } \\
\text { Australia and } \\
\text { provides insight on } \\
\text { a global level. }\end{array}$ & $\begin{array}{l}2518 \text { respondents } \\
\text { from Australia }\end{array}$ & $\begin{array}{l}\text { n.a., focus on the } \\
\text { study of attitudes } \\
\text { toward plastic }\end{array}$ & $\begin{array}{l}\text { Eighty percent of respondents } \\
\text { indicated a desire to reduce } \\
\text { plastic use, and the majority of } \\
\text { respondents believe that study } \\
\text { and glass are more } \\
\text { environmentally friendly } \\
\text { packaging materials than } \\
\text { plastics. However, many } \\
\text { respondents do not translate } \\
\text { their aspiration to reduce } \\
\text { plastic use into action. They } \\
\text { place the bulk of the } \\
\text { responsibility for reducing the } \\
\text { use of disposable plastic on } \\
\text { industry and the government. }\end{array}$ \\
\hline
\end{tabular}

\section{Findings}

\subsection{Diversity of Samples}

Our literature review showed that the studies on consumer motivations to buy food in environmentally friendly packaging have been conducted on a diversity of samples across various countries. With regards to the samples, approximately half of the studies are conducted on less than 200 consumers. There is even a study with only eight consumers [23]. Among the larger studies $(n>300)$ that examined consumer attitudes and purchasing intentions are the study of Bech-Larsen [24], with 351 Danish consumers, the study of Th $\varphi$ gersen [25], with a sample of 1002 Danish consumers, the study of Rokka and Uusitalo [26], with 330 Finish consumers, the study of Barber [7], with 313 US consumers, and the study of Koenig-Lewis, Palmer, Dermody, and Urbye [27], with a sample of 312 Norwegian consumers. The largest samples are those from China $(n=781)$ [28] and Australia $(n=2518)$ [1]. Moreover, we identified that four studies were conducted among Dutch consumers, and other studies were done in Denmark, Finland, France, India, Germany, New Zealand, Norway, Portugal, South Africa, Sweden, the USA, and the West Indies. We found no comparative or cross-cultural investigations. Only one study drew on different samples in its multi-study research design. For example, the study of Magnier and Schoormans [29] reported on the results from a sample of 185 French consumers in Study 1 and on a sample of 119 Dutch consumers in Study 2.

\subsection{Theoretical Lenses}

Despite the wide diversity of theoretical perspectives available and presented in the theoretical part of this chapter to investigate consumers' motivations to purchase food and products in environmentally friendly packaging [5], most reviewed studies drew on Ajzen's [4] Theory of Planned Behavior. One of the earlier studies that used this theory was published in 1996 by Bech-Larsen [24]. The recent studies of Parakash and Pathak [2] and Steenis et al. [30] used the Theory of Planned Behavior in their studies 
as well. Additionally, one study drew on the theory of moral decision making by Schwartz [31] (i.e., Th $\varphi$ gersen [25]). Two studies drew on Maslow's [32] theory of "meta needs", namely Van Birgelen et al. [33]; Martinho et al. [14]. The remaining studies were either explorative or used general theoretical arguments to build their hypotheses. Table 1 provides an overview of all the theories used in the studies.

\subsection{Antecedents of the Consumers' Purchasing of Foods in Environmentally Friendly Packaging}

\subsubsection{Demographics}

There are only a few studies that have explicitly addressed the demographic characteristics of consumers who buy food in environmentally friendly packaging. Among them is one study that examined the perceptions of younger consumers [2] and another study that examined the perceptions of aging consumers [43]. With respect to younger consumers, Prakash and Pathak [2] found that young Indian consumers possess environmental consciousness and are concerned with environmental protection. For these young individuals, personal norms emerged as the strongest predictor of their intention of purchasing environmentally friendly packaged products, showing that young Indian consumers care about environmental protection. In turn, aging consumers noted that price, safety, size of packaging, and the ability to recycle are the most important characteristics of packaging [43].

With regards to gender, there are mixed findings. Some of the earlier studies suggested that gender is an important factor that predicts consumers' choice of foods in environmentally friendly packaging. This is because women, with their higher emotionality, are more concerned with the environment. However, we also found a study that shows that gender plays no role in the consumer perception of packaging [41].

With regards to education, Tüzemen and Kuru [57] found that the lowest level of education was associated with more focus on the product rather than packaging. It was found that consumers with higher education and income levels ascribe more meaning to packaging and have more environmental sensitivities, while the least educated group of consumers is most concerned with the price of the overall product.

Finally, the study of Rokka and Uusitalo [26], on a sample of 330 Finnish consumers, showed that there was no significant demographic difference among consumers who preferred products in environmentally friendly packaging and those who did not pay any attention to this. The authors proposed that it may be that consumer background variables are no longer relevant. In turn, they proposed that other consumer attributes, such as interests, preferences, and tastes, can better explain consumer choices.

\subsubsection{Internal Factors}

Positive attitudes toward environmentally friendly packaging. Following Ajzen's Theory of Planned Behavior [39], several studies have shown that consumer attitude plays an important role in predicting consumers' intention to purchase food in environmentally friendly packaging. For example, the study of Prakash and Pathak [2] showed that an individual's pro-environmental attitude has a significant positive influence on the consumer's intention to purchase environmentally friendly packaged products. The authors showed that Indian youth have strong concerns and are ready to protect the environment through their pro-environmental purchasing behavior. This is in line with the findings of Hartmann and Apaolaza-Ibanez [65] and Mostafa [66] who found that consumers' environmental concern predicts their eco-friendly behavior. This finding is also in line with the study of Yadav and Pathak [67], who found that Indian youth have strong environmental concerns and prefer to buy green products.

The recent study of Dilkes-Hoffman et al. [1] focused entirely on public attitudes toward plastics. In a sample of 2518 Australian consumers, scholars found that the public views plastic as a serious environmental problem. Eighty percent of the consumers indicated their interest in decreasing their use of plastic. The majority of the respondents indicated that they view cartons and glass as more 
environmentally friendly solutions than plastic. At the same time, the study showed that there is a big gap between consumer aspirations and their actual behavior towards reducing the use of plastic packaging. Many Australian consumers place the responsibility for reducing the use of plastic on industry and the government [1].

Lack of knowledge about the negative environmental effects of packaging. The literature review revealed that one of the largest challenges that hinders consumer purchasing of food in environmentally friendly packaging is their limited knowledge about the environmental effects of packaging. For example, in a sample of 155 Swedish consumers, Lindh, Olsson, and Williams [3] found that only eight percent of consumers were aware of the negative effects of packaging on the environment. Furthermore, this study showed that a majority of the Swedish consumers surveyed were aware of their shortcomings in judging the environmental status of food packaging, indicating the need for guidance. They also reported that their purchase is usually guided by the convenience, where 'easy open', 'resealable', 'ease of transport', 'disposal', and 'storage in the home' were mentioned as primary drivers of purchases. Furthermore, a sample of 82 consumers from Trinidad, West Indies, Peters-Texeira and Badrie [41] showed that $36.6 \%$ consumers admitted that they do not read the label because of its complexity. Furthermore, 323 South African consumers were found to exhibit limited knowledge of what environmentally friendly packaging is, how to differentiate it from normal packaging, and its benefits [49]. Lindh, Olsson, and Williams [3] found that consumers have a difficult time judging the environmental impacts of packaging. Fifty-six percent stated that they 'don't know' if organic food packaging is environmentally friendly.

Perception of the visual design of packaging. The literature review has shown that there has been persistent interest among scholars in the effects of the visual design of packaging on consumer perceptions of packaging's sustainability. A number of scholars have provided a breadth of evidence on the importance of packaging design on consumers' perceptions of environmentally friendly packaging and their intention to buy food in such packaging. For example, a sample of 82 consumers from Trinidad, West Indies, Peters-Texeira and Badrie [3] found that $85.4 \%$ of consumers admitted that the attractiveness of the packaging drives their purchasing decision. Furthermore, Magnier and Schoormans [68] found that packaging is the main means of communication regarding the environmental friendliness of the packaging. When looking at the influence of packaging design elements, such as material and color, on consumers' evaluation of the environment-friendliness of the packaging, the authors discovered that the packaging made of a fiber-based material was perceived as more environmentally friendly than the plastic packaging. Moreover, these perceptions were even stronger when an environmental claim about the package (i.e., eco-label) was displayed on the packaging. Furthermore, Steenis et al. [30] found that consumers' assessments of the environmental friendliness of packaging are highly influenced by graphical cues on the packaging. Moreover, environmentally friendly packaging makes consumers think that the food in such packaging tastes better and is of better quality. Similar findings were attained by Magnier and Schoormans [29] and Magnier and Crie [23].

Perception of the packaging's convenience of usage. There is persistent evidence that the consumers' choice of products is defined by convenience factors. Although our sample of the reviewed studies included twenty-five years of research, it was interesting to observe that one of the earlier studies signaled that the consumer purchasing behavior was guided by convenience [22], and one of the latest studies offered a very similar finding [3]. Specifically, Lindh, Olsson, and Williams [3], on a sample of Swedish consumers, showed that 'easy open', 'resealable', 'ease of transport', 'disposal', and 'storage in the home' were mentioned as the primary drivers of purchases. Less than $10 \%$ of consumers mentioned the environmental aspects of packaging as being important to them when they make a purchasing decision. For example, 'easy to open' was mentioned by more than $25 \%$ of the respondents. In turn, the possibility to 'reseal' a package was considered by $27 \%$ of the consumers. Moreover, 'packaging size' was mentioned by $24 \%$, of which a clear majority regarded size in the sense of convenience, i.e., 'It has to fit in the refrigerator', or in other storage space at home. This is especially interesting, given that the latest studies signaled that consumers are increasingly becoming more aware of the 
environmental implications of plastic packaging. However, convenience plays a more important role in consumer purchasing decisions. This finding has important implications for packaging manufacturers and suggests that environmentally friendly packaging needs to be both convenient and environmentally friendly.

\subsubsection{External Factors}

Cultural differences in consumer purchasing behaviors. Our review showed that only three studies involved multicultural groups of consumers. The study of Magnier and Schoormans [29] included two studies, one that was conducted on a sample of 185 French individuals and a second study that involved 119 Dutch consumers. However, the findings were not discussed in light of the cultural differences between these two groups of consumers.

In turn, the study of Jerzyk [53] was conducted on a sample of 161 Polish and French students. While the author did not differentiate between the two groups of consumers, she acknowledged that "the studies conducted in Poland and France also indicate that the level of economic development and market maturity may significantly affect customers' needs in terms of sustainable packaging communication" [53] (p. 635). The author concluded that "further research ought to be conducted on larger samples and combined with extensive qualitative studies, which could help to better understand and interpret respondents' answers" [53] (p. 635).

Finally, the study of Herbes et al. [61] is the only study that aimed to compare consumers' attitudes toward biobased packaging. The study included three samples, i.e., consumers from Germany ( $n=948)$, the U.S. $(n=610)$, and France $(n=443)$. The comparative analysis demonstrated that German consumers favor reusability of packaging, and French and American consumers favor recyclability.

Higher price of foods (in general) in environmentally friendly packaging. Considering that environmentally friendly packaging entails a higher price for the final products, there has been a significant line of research aiming to investigate the extent to which higher price can serve as a barrier to purchasing. However, mixed findings were attained in this regard. On the one hand, the research shows that a slightly increased price has no effect on consumer purchasing behaviors, even in developing countries. On the other hand, another body of research shows that the higher price of products in environmentally friendly packaging affects consumer purchasing behavior, especially if these consumers have a lower education level and low-income jobs. Specifically, Lindh, Olsson, and Williams [3] found that $86 \%$ of Swedish respondents were willing to pay an extra 0.94 SEK, or $6 \%$, more for food products that cost 15 SEK with environmentally friendly packaging. Those in the organic food consumer group were willing to pay statistically significantly more, i.e., the mean value was 1.25 SEK, or 8\%, more. In the Netherlands, Van Birgelen, Semeijn, and Keicher [33] found that approximately $44 \%$ of the sample would be willing to pay a premium of $€ 0.10(\$ 0.13)$ for environmentally friendly packaging, $6 \%$ would be willing to pay an additional $€ 0.20(\$ 0.26)$, and $17 \%$ of the respondents indicated a willingness to pay an additional amount of $€ 0.50$ (\$0.64). Furthermore, Prakash and Pathak [2] found that in a less developed economy, such as India, young consumers are ready to pay more if they can obtain eco-friendly products. The authors also found that young Indian consumers prefer to buy products from companies behaving in an environmentally responsible manner. In a related study, Martinho et al. [14] found that $70 \%$ of consumers are willing to pay a premium of between $5 \%$ and $1 \%$ for products in environmentally friendly packaging.

In turn, the study of Martinho et al. [14] of consumers from Portugal showed that price is an important predictor of consumers' purchasing of products contained/wrapped in sustainable packaging. Thirty percent of consumers were not willing to pay more for products in environmentally friendly packaging, and seventy percent of consumers were willing to pay only $1-5 \%$ more. Furthermore, a global consumers survey by McKinsey in Brazil, Canada, China, France, Germany, India, the UK, and the USA, which linked consumer inconsistencies in their attitudes and behaviors with willingness to pay, revealed that $53 \%$ of consumers were concerned about environmental issues, but were unwilling to take actions in purchasing decisions, while a further $13 \%$ were willing to pay 
more but currently did not do so [69]. Consumers believe that manufacturers are responsible for providing sustainable packaging without passing along any additional costs [44].

To reconcile the issue of the higher price for products in environmentally friendly packaging, two recent studies have offered possible approaches. For example, a sample of 343 consumers from Northern India, Singh and Pandey [58] showed that six distinct but highly interrelated values can influence the buyers' willingness to pay a price premium for green packaging. These are the epistemic value of green packaging, functional value, economic value, symbolic value, altruistic values, and biospheric value. In turn, Hao, Liu, Chen, Sha, Ji, and Fan [28] found that four factors can affect the consumers' willingness to pay, i.e., environment, green packaging quality, commodity, and packaging price.

\section{Discussion}

The purpose of this literature review was to bring together all the research published in the past 25 years that could help to answer the following question: Which factors influence the consumers' decision to purchase food in environmentally friendly packaging? To answer this question, we first reviewed the available theories that can help to explain which factors influence consumers' choice of foods with environmentally friendly packaging. We also reviewed the extant empirical research on the topic, synthesizing the findings of 31 studies. Based on the extant empirical research, we discovered that, thus far, most studies have addressed only a limited set of factors that predict consumer's purchasing of food in environmentally friendly packaging. We present these factors in Table 2.

Table 2. Extant explanations and future research opportunities for the study of predictors of consumers' decision to purchase food in environmentally friendly packaging.

\begin{tabular}{lll}
\hline & Extant Explanations & Suggestions for Future Research \\
\hline \multicolumn{2}{l}{ Age } & Demographics \\
\hline$-\quad$ Gender & $-\quad$ Family composition \\
$-\quad$ Education & & \\
\end{tabular}

Internal factors

\begin{tabular}{|c|c|}
\hline $\begin{array}{l}\text { - Positive attitude toward environmentally } \\
\text { friendly packaging; } \\
\text { - Lack of knowledge about the negative } \\
\text { environmental effects of packaging; } \\
\text { - } \quad \begin{array}{l}\text { Perception of the visual design of packaging; } \\
\text { - }\end{array} \quad \begin{array}{l}\text { Perception of the packaging's convenience } \\
\text { of usage; }\end{array}\end{array}$ & $\begin{array}{ll}- & \text { Values; } \\
- & \text { Personal needs; } \\
- & \text { Motivation; } \\
- & \text { Environmental knowledge; } \\
- & \text { Awareness; } \\
- & \text { Emotions; } \\
- & \text { Locus of control; } \\
- & \text { Responsibilities; } \\
- & \text { Purchasing priorities; } \\
- & \text { Behaviours. }\end{array}$ \\
\hline \multicolumn{2}{|c|}{ External factors } \\
\hline $\begin{array}{l}\text { Cultural differences in consumer purchasing } \\
\text { behaviors (societal behaviors); } \\
\text { - Higher price of foods (in general) in } \\
\text { environmentally friendly packaging. }\end{array}$ & $\begin{array}{ll}- & \text { Institutional; } \\
- & \text { Economic; } \\
- & \text { Social; } \\
\text { - } & \text { Other cultural explanations; } \\
\text { - } & \text { Stakeholder responsibilities. }\end{array}$ \\
\hline
\end{tabular}


While the existing findings provide important empirical evidence, we also observe that, in light of emerging theories about consumers' pro-environmental behaviors, the spectrum of possible antecedents of consumer purchasing behaviors is as yet very limited in the sustainable packaging domain of research. In contrast, as we demonstrate in the Theoretical Background section of this paper, there is a large diversity of theories and frameworks in the general pro-environmental behavior literature that can aid sustainable packaging research. Consequently, below we propose that future research can draw on the following six research opportunities:

(a) Going beyond Ajzen's [39] theoretical explanations of consumer purchasing intentions;

(b) Examining a broader set of predictors;

(c) Drawing on more interconnected complex models that include both internal and external factors;

(d) Conducting cross-cultural comparative studies;

(e) Addressing the gap between attitudes and behaviors;

(f) Considering the role of organizations and government in the transition to more sustainable consumer purchasing behavior, rather than only searching for individual predictors of behaviors.

Below, we briefly discuss each of these points and offer suggestions for future research.

Our first suggestion is to go beyond Ajzen's [39] theoretical explanations of consumer purchasing behaviors. Through conducting the literature review, we noticed that a majority of the empirical studies draw on and/or refer to Ajzen's Theory of Planned Behavior [39]. The theory suggests that three factors predict an individual's intention toward a particular behavior, namely, attitude toward the behavior, subjective norms, and perceived control. Together, these factors are suggested to influence the intention to perform the behavior, which leads to the actual performance of the behavior. However, while many studies refer to Ajzen's theory, the studies themselves actually go beyond the theory's explanations. For example, Steenis et al. [30] drew on Ajzen's theory, while actually studying the material/structural cues that form judgments about packaging sustainability. Orzan et al. [56] also used Ajzen's theory but studied two motivational factors that influence the decision to buy ecological packaging, i.e., saving by recycling and protecting the environment. We encourage future research to take note of many other theories that are available to explain consumers' purchasing of foods in environmentally friendly packaging.

Consequently, we also suggest focusing on the examination of a broader range of predictors of consumers' purchasing of foods in environmentally friendly packaging. While many earlier studies have focused on the examination of attitudes and related factors, recent studies have begun to move beyond this limited focus. For example, the study of Singh and Pandey [58] focused on the examination of six distinct but highly interrelated values that influence buyers' willingness to pay a price premium for green packaging. They include the epistemic value of green packaging, functional value, economic value, symbolic value, altruistic values, and biospheric value. Ottman and Herbert [70] suggested that the following four needs guide consumers' green purchasing behaviors: The need for information, the need for control, the need to make a difference, and the need to remain current. If a product satisfies these needs, then the consumer will be more eager to buy it. These are just a few examples of theoretical perspectives that could guide future research on the reasons consumers choose to buy foods in environmentally friendly packaging. Based on the theories we reviewed in this paper, we offer an overview of new research ideas in Table 2. However, future research is needed to develop more explanations.

This leads to our next point, which is, according to the findings of the review, that the research needs to utilize more holistic explanations for consumer purchasing behaviors. The aforementioned study by Singh and Pandey [58] has shown that distinct but highly interrelated values influence buyers' willingness to pay a price premium for green packaging. Another opportunity can be provided by Kollmuss and Agyeman [5] and their "pro-environmental consciousness" model. It includes the following three sets of factors explaining individual motivations to act pro-environmentally: (a) Demographic factors, (b) external factors (e.g., institutional, economic, social, and cultural factors), 
and (c) internal factors (e.g., motivation, environmental knowledge, awareness, values, attitudes, emotion, locus of control, responsibilities, and purchasing priorities, for example, functionality). This framework offers many more explanations than the theory of Ajzen [39]. Specifically, as our review shows, factors such as knowledge and awareness are important predictors of consumer purchasing behaviors. We also see great value in comparative studies, in which cultural differences in purchasing behaviors can be observed.

Indeed, cultural aspects of consumers' purchasing perceptions and behaviors were only addressed in three studies. Two studies included multinational samples; however, the authors did not perform any comparative analyses [29,53]. In turn, the study of Herbes et al. [61], which included consumers from Germany, the U.S. and France, revealed that there was a difference in consumer attitudes. Specifically, they found that German consumers favor reusable packaging, and French and American consumers favor recyclability. However, if we critically look at the samples, they do not include consumers from less economically developed countries or institutionally significantly different cultures. However, the research shows that cultures determine the consumers' value system and guide their purchasing behaviors [71]. Cultural differences also explain the consumer's view of whether pro-environmental behavior is their responsibility or that of the government [1]. Therefore, we suggest that research on consumers' choice of foods in environmentally friendly packaging would significantly benefit from cross-cultural comparative studies.

One of the critical points that we suggest needs much more research in the future is the gap between attitudes and behaviors. Our literature review showed that, while consumers are aware of the negative effects of plastic for the world and the environment, they do not necessarily connect this with their purchasing behavior. Indeed, the research shows that, when thinking about environmentally friendly purchasing, consumers mainly think about its functionality or price. For example, in a study by Young [72], 40-45\% of consumers indicated that their purchasing preference is mostly driven by the package functionality and protection of products, and sustainable features were a secondary factor. Although consumers recognize their responsibility for pro-environmental purchasing, they perceive their obligation to be secondary to the responsibility of manufacturers. Furthermore, a global consumer survey by McKinsey in Brazil, Canada, China, France, Germany, India, the UK, and the USA, which linked consumer inconsistencies in their attitudes and behaviors with their willingness to pay, revealed that $53 \%$ of consumers were concerned about environmental issues but were unwilling to take actions in purchasing decisions, while a further $13 \%$ were willing to pay more but currently did not do so [26]. Therefore, more research is needed with a focus on behavioral changes in consumer purchasing behavior, especially with regards to purchasing foods in environmentally friendly packaging.

Finally, serious consideration needs to be given as to whether users should take the leading role in the adoption of the pro-environmental packaging. Much of the reviewed research signaled that consumers are willing to make pro-environmental purchases, but they do not observe the reason for the higher cost, or why the choice of whether to buy or not to buy foods in environmentally packaging should be theirs. Many consumers think that organizations and the government should play a much more significant role in this. For example, in their study, Dilkes-Hoffman et al. [1] asked respondents from Australia to 'indicate the level of responsibility of each of the following parties (Government, Industry and Individuals) for reducing the use of disposable plastic'. The results of the study show that $64 \%$ of consumers perceive companies/industry to be responsible for the reduction of the plastic use. Others expect the government to take care of the plastic reduction and only $7 \%$ of the respondents believed that reduction in plastic use was their responsibility. This is in line with the initiatives that are being implemented by some businesses. One example is supermarkets' initiative to decrease the use of free plastic bags. However, more research is needed to explore further opportunities in which all parties, i.e., government, industry, and individuals, can collaborate in decreasing plastic use in packaging. 


\section{Conclusions}

The purpose of this paper was to present a systematic literature review of all studies on the predictors of consumer food purchasing in environmentally friendly packaging published in the period 1994-2019. We sought to answer the question: Which factors influence the consumers' decision to purchase food in environmentally friendly packaging? The review revealed that, although the extant research is growing, it is very limited in terms of the theories utilized to explain consumer purchasing behaviour and in the range of the tested predictors of the consumers' purchasing of foods in environmentally friendly packaging. Among the existing explanations are demographics, consumer attitudes, knowledge about the environmental effects of packaging, visual designs, functionality, cross-cultural differences, and affordability. The future research on consumers' decision to purchase food in environmentally friendly packaging will benefit from (a) employing diverse theoretical explanations of consumer purchasing behaviors; (b) examining a broader set of predictors; (c) drawing on more interconnected complex models that include both internal and external factors; (d) conducting cross-cultural comparative analysis; (e) addressing the gap between attitudes and behaviors; and (f) considering the role of organizations and government in the transition to more sustainable consumer purchasing behavior, rather than only searching for individual predictors of consumers' purchasing behaviors.

Author Contributions: Writing, I.P.; supervision, B.A.G.B. and P.C.v.d.S.; review and editing, B.A.G.B. and P.C.v.d.S. All authors have read and agreed to the published version of the manuscript.

Funding: This research received no external funding.

Conflicts of Interest: The authors declare no conflict of interest.

\section{References}

1. Dilkes-Hoffman, L.S.; Pratt, S.; Laycock, B.; Ashworth, P.; Lant, P.A. Public attitudes towards plastics. Resour. Conserv. Recycl. 2019, 147, 227-235. [CrossRef]

2. Prakash, G.; Pathak, P. Intention to buy eco-friendly packaged products among young consumers of India: A study on developing nation. J. Clean. Prod. 2017, 141, 385-393. [CrossRef]

3. Lindh, H.; Olsson, A.; Williams, H. Consumer Perceptions of Food Packaging: Contributing to or Counteracting Environmentally Sustainable Development? Packag. Technol. Sci. 2016, 29, 3-23. [CrossRef]

4. Ajzen, I.; Fishbein, M. Understanding Attitudes and Predicting Social Behaviour; Pearson: London, UK, 1980.

5. Kollmuss, A.; Agyeman, J. Mind the Gap: Why do people act environmentally and what are the barriers to pro-environmental behavior? Environ. Educ. Res. 2002, 8, 239-260. [CrossRef]

6. Kaufmann, H.R.; Panni, M.F.A.K.; Orphanidou, Y. Factors Affecting Consumers ' Green Purchasing Behavior. Amifiteratru Econ. 2012, 14, 50-69.

7. Barber, N. "Green" wine packaging: targeting environmental consumers. Int. J. Wine Bus. Res. 2010, 22, 423-444. [CrossRef]

8. Borden, R.J. One More Look at Social and Environmental Psychology: Away from the Looking Glass and into the Future. Personal. Soc. Psychol. Bull. 1977, 3, 407-411. [CrossRef]

9. Owens, S. 'Engaging the Public': Information and Deliberation in Environmental Policy. Environ. Plan. A Econ. Sp. 2000, 32, 1141-1148. [CrossRef]

10. Jensen, B.B. Knowledge, Action and Pro-environmental Behaviour. Environ. Educ. Res. 2002, 8, 325-334. [CrossRef]

11. Goldstein, N.J.; Cialdini, R.B.; Griskevicius, V. A Room with a Viewpoint: Using Social Norms to Motivate Environmental Conservation in Hotels. J. Consum. Res. 2008, 35, 472-482. [CrossRef]

12. Newhouse, N. Implications of Attitude and Behavior Research for Environmental Conservation. J. Environ. Educ. 1990, 22, 26-32. [CrossRef]

13. Courtenay-Hall, P.; Rogers, L. Gaps in Mind: Problems in environmental knowledge-behaviour modelling research. Environ. Educ. Res. 2002, 8, 283-297. [CrossRef]

14. Martinho, G.; Pires, A.; Portela, G.; Fonseca, M. Factors affecting consumers' choices concerning sustainable packaging during product purchase and recycling. Resour. Conserv. Recycl. 2015, 103, 58-68. [CrossRef] 
15. Hines, J.M.; Hungerford, H.R.; Tomera, A.N. Analysis and Synthesis of Research on Responsible Environmental Behavior: A Meta-Analysis. J. Environ. Educ. 1987, 18, 1-8. [CrossRef]

16. Hungerford, H.R.; Volk, T.L. Changing Learner Behavior Through Environmental Education. J. Environ. Educ. 1990, 21, 8-21. [CrossRef]

17. Sia, A.P.; Hungerford, H.R.; Tomera, A.N. Selected Predictors of Responsible Environmental Behavior: An Analysis. J. Environ. Educ. 1986, 17, 31-40. [CrossRef]

18. Stern, P.C.; Dietz, T.; Kalof, L. Value Orientations, Gender, and Environmental Concern. Environ. Behav. 1993, 25, 322-348. [CrossRef]

19. McLaren, N.; Bullock, D.; Simon, Y.N. Tomorrow's World: Britain's Share in a Sustainable Future; Routledge: London, UK, 2013.

20. Blake, J. Overcoming the 'value-action gap' in environmental policy: Tensions between national policy and local experience. Local Environ. 1999, 4, 257-278. [CrossRef]

21. Tranfield, D.; Denyer, D.; Smart, P. Towards a Methodology for Developing Evidence-Informed Management Knowledge by Means of Systematic Review. Br. J. Manag. 2003, 14, 207-222. [CrossRef]

22. van Dam, Y.K.; van Trijp, H.C.M. Consumer perceptions of, and preferences for, beverage containers. Food Qual. Prefer. 1994, 5, 253-261. [CrossRef]

23. Magnier, L.; Crié, D. Communicating packaging eco-friendliness. Int. J. Retail Distrib. Manag. 2015, 43, 350-366. [CrossRef]

24. Bech-Larsen, T. Danish consumers' attitudes to the functional and environmental characteristics of food packaging. J. Consum. Policy 1996, 19, 339-363. [CrossRef]

25. Thøgersen, J. The ethical consumer. Moral norms and packaging choice. J. Consum. Policy 1999, 22, 439-460. [CrossRef]

26. Rokka, J.; Uusitalo, L. Preference for green packaging in consumer product choices - Do consumers care? Int. J. Consum. Stud. 2008, 32, 516-525. [CrossRef]

27. Koenig-Lewis, N.; Palmer, A.; Dermody, J.; Urbye, A. Consumers' evaluations of ecological packaging Rational and emotional approaches. J. Environ. Psychol. 2014, 37, 94-105. [CrossRef]

28. Hao, Y.; Liu, H.; Chen, H.; Sha, Y.; Ji, H.; Fan, J. What affect consumers' willingness to pay for green packaging? Evidence from China. Resour. Conserv. Recycl. 2019, 141, 21-29. [CrossRef]

29. Magnier, L.; Schoormans, J. Consumer reactions to sustainable packaging: The interplay of visual appearance, verbal claim and environmental concern. J. Environ. Psychol. 2015, 44, 53-62. [CrossRef]

30. Steenis, N.D.; van Herpen, E.; van der Lans, I.A.; Ligthart, T.N.; van Trijp, H.C.M. Consumer response to packaging design: The role of packaging materials and graphics in sustainability perceptions and product evaluations. J. Clean. Prod. 2017, 162, 286-298. [CrossRef]

31. Schwartz, S.H. Elicitation of moral obligation and self-sacrificing behavior: An experimental study of volunteering to be a bone marrow donor. J. Pers. Soc. Psychol. 1970, 15, 283-293. [CrossRef]

32. Maslow, A.H. A Theory of Metamotivation: the Biological Rooting of the Value-Life. J. Humanist. Psychol. 1967, 7, 93-127. [CrossRef]

33. van Birgelen, M.; Semeijn, J.; Keicher, M. Packaging and Proenvironmental Consumption Behavior. Environ. Behav. 2009, 41, 125-146. [CrossRef]

34. Meffert, H. Umweltbewusstes Konsumentenverhalten. Marketing 1993, 15, 51-54.

35. Van Dam, Y.K. Environmental assessment of packaging: The consumer point of view. Environ. Manag. 1996, 20,607-614. [CrossRef] [PubMed]

36. Hoyer, W.D. An Examination of Consumer Decision Making for a Common Repeat Purchase Product. J. Consum. Res. 1984, 11, 822-829. [CrossRef]

37. Costall, B.; Naylor, R.J.; Neumeyer, J.L. Dissociation by the aporphine derivatives of the stereotypic and hyperactivity responses resulting from injections into the nucleus accumbens septi. J. Pharm. Pharmacol. 1975, 27, 875-877. [CrossRef]

38. Gutman, J. A Means-End Chain Model Based on Consumer Categorization Processes. J. Mark. 1982, 46, 60-72. [CrossRef]

39. Ajzen, I. The theory of planned behavior. Organ. Behav. Hum. Decis. Process. 1991, 50, 179-211. [CrossRef]

40. Haines, G.H.; Howard, J.A.; Sheth, J.N. The Theory of Buyer Behavior; Wiley: New York, NY, USA, 1969.

41. Peters-Texeira, A.; Badrie, N. Consumers' perception of food packaging in Trinidad, West Indies and its related impact on food choices. Int. J. Consum. Stud. 2005, 29, 508-514. [CrossRef] 
42. Bem, D.J. Self-perception: An alternative interpretation of cognitive dissonance phenomena. Psychol. Rev. 1967, 74, 183-200. [CrossRef]

43. Duizer, L.M.; Robertson, T.; Han, J. Requirements for packaging from an ageing consumer's perspective. Packag. Technol. Sci. 2009, 22, 187-197. [CrossRef]

44. Nordin, N.; Selke, S. Social aspect of sustainable packaging. Packag. Technol. Sci. 2010, 23, 317-326. [CrossRef]

45. Venter, K.; van der Merwe, D.; de Beer, H.; Kempen, E.; Bosman, M. Consumers' perceptions of food packaging: an exploratory investigation in Potchefstroom, South Africa. Int. J. Consum. Stud. 2011, 35, 273-281. [CrossRef]

46. Vilnai-Yavetz, I.; Koren, R. Cutting through the clutter: purchase intentions as a function of packaging instrumentality, aesthetics, and symbolism. Int. Rev. Retail. Distrib. Consum. Res. 2013, 23, 394-417. [CrossRef]

47. Rafaeli, A.; Vilnai-Yavetz, I. Instrumentality, aesthetics and symbolism of physical artifacts as triggers of emotion. Theor. Issues Ergon. Sci. 2004, 5, 91-112. [CrossRef]

48. Bagozzi, R.P.; Gopinath, M.; Nyer, P.U. The Role of Emotions in Marketing. J. Acad. Mark. Sci. 1999, 27, 184-206. [CrossRef]

49. Scott, L.; Vigar-Ellis, D. Consumer understanding, perceptions and behaviours with regard to environmentally friendly packaging in a developing nation. Int. J. Consum. Stud. 2014, 38, 642-649. [CrossRef]

50. Fernqvist, F.; Olsson, A.; Spendrup, S. What's in it for me? Food packaging and consumer responses, a focus group study. Br. Food J. 2015, 117, 1122-1135. [CrossRef]

51. Banerjee, B.; McKeage, K. How green is my value: Exploring the relationship between environmentalism and materialism. Adv. Consum. Res. 1994, 21, 147-152.

52. Lord, C.G.; Ross, L.; Lepper, M.R. Biased assimilation and attitude polarization: The effects of prior theories on subsequently considered evidence. J. Pers. Soc. Psychol. 1979, 37, 2098-2109. [CrossRef]

53. Jerzyk, E. Design and Communication of Ecological Content on Sustainable Packaging in Young Consumers' Opinions. J. Food Prod. Mark. 2016, 22, 707-716. [CrossRef]

54. Kotler, P.; Keller, K.L. Marketing Management, 15th ed.; Pearson: London, UK, 1997; ISBN 13: 9781292093239.

55. Fishbein, M. Predicting and Changing Behavior; Psychology Press: New York, NY, USA, 2011; ISBN 9780203838020.

56. Orzan, G.; Cruceru, A.; Bălăceanu, C.; Chivu, R.-G. Consumers' Behavior Concerning Sustainable Packaging: An Exploratory Study on Romanian Consumers. Sustainability 2018, 10, 1787-1798. [CrossRef]

57. Tuzemen, A.; Kuru, O. Does the consumer want to be greened? The place of green packaging applications with green supply chain function in consumer perception. Int. J. Contemp. Econ. Adm. Sci. 2018, 8, 200-216.

58. Singh, G.; Pandey, N. The determinants of green packaging that influence buyers' willingness to pay a price premium. Australas. Mark. J. 2018, 26, 221-230. [CrossRef]

59. Sheth, J.N.; Newman, B.I.; Gross, B.L. Why we buy what we buy: A theory of consumption values. J. Bus. Res. 1991, 22, 159-170. [CrossRef]

60. Smith, J.B.; Colgate, M. Customer Value Creation: A Practical Framework. J. Mark. Theory Pract. 2007, 15, 7-23. [CrossRef]

61. Herbes, C.; Beuthner, C.; Ramme, I. Consumer attitudes towards biobased packaging - A cross-cultural comparative study. J. Clean. Prod. 2018, 194, 203-218. [CrossRef]

62. Trivedi, R.H.; Patel, J.D.; Acharya, N. Causality analysis of media influence on environmental attitude, intention and behaviors leading to green purchasing. J. Clean. Prod. 2018, 196, 11-22. [CrossRef]

63. Leonidou, L.C.; Leonidou, C.N.; Kvasova, O. Antecedents and outcomes of consumer environmentally friendly attitudes and behaviour. J. Mark. Manag. 2010, 26, 1319-1344. [CrossRef]

64. Boesen, S.; Bey, N.; Niero, M. Environmental sustainability of liquid food packaging: Is there a gap between Danish consumers' perception and learnings from life cycle assessment? J. Clean. Prod. 2019, 210, 1193-1206. [CrossRef]

65. Hartmann, P.; Apaolaza-Ibáñez, V. Consumer attitude and purchase intention toward green energy brands: The roles of psychological benefits and environmental concern. J. Bus. Res. 2012, 65, 1254-1263. [CrossRef]

66. Mostafa, M.M. Shades of green: A psychographic segmentation of the green consumer in Kuwait using self-organizing maps. Expert Syst. Appl. 2009, 36, 11030-11038. [CrossRef]

67. Yadav, R.; Pathak, G.S. Young consumers' intention towards buying green products in a developing nation: Extending the theory of planned behavior. J. Clean. Prod. 2016, 135, 732-739. [CrossRef] 
68. Magnier, L.; Schoormans, J. How Do Packaging Material, Colour and Environmental Claim Influence Package, Brand and Product Evaluations? Packag. Technol. Sci. 2017, 30, 735-751. [CrossRef]

69. World Business Council for Sustainable Development (WBCSD). Sustainable Consumption Facts and Trend: From a Business Perspective; WBCSD: Geneva, Switzerland, 2008.

70. Ottman, J. Green Marketing: Opportunity for Innovation. J. Sustain. Prod. Des. 1998, 60, 136-167.

71. Liu, Y.; Segev, S. Cultural orientations and environmental sustainability in households: A comparative analysis of Hispanics and non-Hispanic Whites in the United States. Int. J. Consum. Stud. 2017, 41, 587-596. [CrossRef]

72. Young, S. Packaging and the Environment: A Cross-Cultural Perspective. Des. Manag. Rev. 2010, 19, 42-48. [CrossRef]

(C) 2019 by the authors. Licensee MDPI, Basel, Switzerland. This article is an open access article distributed under the terms and conditions of the Creative Commons Attribution (CC BY) license (http://creativecommons.org/licenses/by/4.0/). 